\title{
Urological Diseases among 50 Composers
}

\author{
Darko Breitenfeld ${ }^{1}$, Mislav Pap ${ }^{1}$, Josip Parazajder ${ }^{1}$, Ankica Akrap ${ }^{1}$, \\ Silva Butković Soldo², Ivana Rešetar ${ }^{1}$ \\ ${ }^{1}$ Croatian physicians' music society (CMA), Zagreb, Croatia; ${ }^{2}$ Faculty of Medicine J.J. \\ Strossmayer University of Osijek, Osijek, Croatia
}

\begin{abstract}
Exploring more than thousand composers' pathographies we have found 50 cases of urological and renal diseases among composers. The most important cases are presented in the form of short pathographies and the others were briefly mentioned in the following list.
\end{abstract}

Key words: urological, renal, diseases, composers, musicians

Copyright (C) 2015 KBCSM, Zagreb

e-mail: alcoholism.kbcsm@gmail.com•www.http//hrcak.srce.hr/acoholism

\section{Introduction}

Among more than thousand composer's pathographies we have sorted out those who had died of illnesses which had been a result or in a way connected to urological and renal diseases [1-16].

Jean-Philippe Rameau (1683-1764)

French composer. He had a calm and steady course of development and it was reflected in the manner of his composing. He was active until the age of 80 , although ailing and weak. His condition deteriorated due to scurvy (vitamin C deficiency) and purulent fever (possibly pyelonephritis with seizuresspasms) and he died suddenly.

Correspondence to:

Darko Breitenfeld

Derenčinova 25, 10000 Zagreb

e-mail: darkobreitenfeld@gmail.com
Jean-Jacques Roussseau (1712-1778)

French composer and philosopher. Problems with erectile dysfunction exacerbated at the end of his life and at the same time problems with urinary bladder occurred (urinary neuropathy, urinary frequency and incontinence because of polyuria, perineal pain, urolithiasis). Although dysuria occurred because of his obsession, phobia and problems with erectile dysfunction, there was probably an organic substrate in the background, due to urinary retention up to kidney and uraemia with partially psychotic clinical presentation. It could have been a chronic gonorrhoea. Very soon he fell into coma and died. There was no significant evidence of the urologic disease found at the autopsy.

Wolfgang Amadeus Mozart (1756-1791)

Austrian composer. Mercury poisoning with uraemia, hyperthyreosis, small subdural 
haematoma and alcohol addiction had been slowly developing and lead to his final symptoms. Mozart's final disease, probably infectious one caused by Streptococcus bacteria, was a relapse of rheumatic fever. It could also have been a kidney disease caused by Streptococcus bacteria or Hennoch - Schönlein purpura. Since he was conducting on his death day, lying in a bed, to requiem soloists during their lesson, it is not possible that developed stage of uraemia could hev been the cause of his death.

Conclusively, what is left are some generalized bacterial infections (coli bacteria, staphylococci, and most probably streptococci), which are the most probable cause of Mozart's terminal illness and its terminal stages.

\section{Nicolo Paganini (1782-1840)}

Italian composer. He had intense disorders in a region of genitourinary organs as a result of chronic gonorrhoea and syphilis. In 1837 due to urethra stricture, probably caused by enlarged prostate, catheter dilatation was done. It is quite possible that Paganini had mixed specific (both tuberculoid and syphilitic) infection of the respiratory tract, which was a cause of his death. He was also a drug (opium) addict.

\section{Gioachino Rossini (1792-1868)}

Italian composer. It is considered that he probably started with ,sweet lifestyle“ at the age of 15 and had been infected with gonorrhoea. Despite all kinds of palliative therapies, the disease had become chronic with many episodes of re-infections due to new adventures (alcohol abuse). Chronic urethritis with purulent liquid and reduced urinary flow occurred because of cicatricial urethral strictures. In 1867/1868 he had been barely recovered after he had acquired pneumonia with severe cough and fever (delirium?). He died due to complications of progressive rectal cancer with chronic heart failure, hypertension and diabetes.

\section{Pyotr-Peter Ilyich Tchaikovsky (1840-1893)}

Russian composer, conductor, music writer, critic and teacher. In 1893, during a business lunch, he deliberately poured himself a glass of unboiled water from the river Neva which was a very unreasonable thing to do since cholera epidemic partly raged in St. Petersburg. He drank the water to his friends' terror. He was sick that night and went straight to bed. He woke up after a few hours in fever (delirious) and feeling stomach spasms, soon diarrhoea and vomiting started. He had stomach spasms and felt an excessive thirst. Muscle ache appeared together with anuria, as a part of uraemia. One day his condition improved, only to get much worse the next day, when he died.

Observers described the situation in the house and at the funeral controversially. Some mentioned strict hygienic measures, isolation of the corpse and iron coffin in which the victims of contagious diseases were usually buried. The others deny all that. It is possible that such information were meant to conceal the truth. Recently it has been suggested that Tchaikovsky had not committed suicide infecting himself with cholera vibrio or some other bacteria, but that he poisoned himself with arsenic. Such an assumption seems reasonable because all the symptoms were characteristic for the acute arsenic poisoning too. Investigations have proved that Nikolay Yakobi, Tchaikovsky's friend from the law School and high official, has summoned a Court of Honour at the Tsar's re- 
quest. The charges were of the seduction of a minor. The session of the Court took place on October 31, and lasted for five hours. The Court decided that Tchaikovsky should commit suicide in order to avoid the scandal. He took arsenic but drank the glass of dirty water from the river Neva to conceal his deed and to repeat symbolically his mother's fate. This version of the story of his death has been published in scientific journals and was confirmed by Alexandra Orlova and Alexander Ivaytov from the Russian Museum in St. Petersburg and Yakobi's widow, Ekaterina Karlova. Similar qualifications were reported by Olga Tchaikovskaya and Nina Berberova. Hypothesis on Tchaikovsky's homosexuality with tragic outcome is also supported by H. Ellis, M. Hirschfeld, Stein and Weinstock, and may be regarded as possible and realistic.

\section{Gaetano Donizetti (1797-1848)}

Italian composer. In 1844 he suffered from bowel disease with possible incontinence (himself said, that he wasn't the master of his own body anymore), (praedelirant) fever attacks with headaches appeared again, but for the first time were accompanied by confusion, weaker mobility, apathy, irritability, hasty behaviour. Due to his poor state Donizetti was escorted by his servant to Ivry hospital. He was placed and cared for very well, but he communicated very little with people, therefore he was removed back home, where he received visitors. He wasted continually, he got periodic fevers, because of urinary retention and he was examined by a series of doctors. They clearly diagnosed a syphilitic disease in quarter stage - progressive paralysis, tabes dorsalis. Every function was suppressed apart from eating and sleeping. However, fever attacks were repeated with inflammation of the urinary tract, he got weaker and weaker and finally suffered a stroke with right-side hemiparesis and total aphasia. He died in agony.

\section{Antonin Dvořak (1841-1904)}

Czech composer. At the end of his life his mental condition became worse. Eruptions of anger occurred, whenever after joy, during sadness or impulsive mood changes. Everybody could notice that he became upset very quickly and then got cheek erythema. His handwriting became less readable. It is considered that he already had first signs of uraemia during that period. Finally he started to have heart problems, complaining about "loss of air" and chest pain. In April 1904 he experienced a strong flu so he was not able to attend the First Bohemian Music Festival. He was a kidney patient (uraemia). During his recovery, on May 1st, he suddenly announced: "I am feeling dizzy...I would rather lie down a little“. Those were his last comprehensible words. Immediately he sunk into an armchair and became semiconscious. He could not articulate words (dysarthria). Doctor Hnatek came immediately and diagnosed stroke, soon after Dvořak died. Sudden onset of symptoms, fast deterioration and history of hypertension lead us to possibility of a hemorrhagic stroke.

\section{Edward Elgar (1857-1934)}

English composer. There were many changes between periods based on creativity and depression. At the end of his life, he was living in a centre for seniors due to his health condition and one year before his death severe ischiadic pain occurred as a result of compression of cancer derived probably from digestive or urological system. 


\section{Ruggiero Leoncavallo (1858-1919)}

Italian composer and librettist. He was especially ill in last years of his life. He suffered from nephritis and its consequences (kidney failure) with uraemia. He died at the age of 61 .

\section{Isaac Albeniz (1860-1909)}

Spanish composer and pianist. As a child, he got a kidney disease called Bright's disease. Nephritis with massive albuminuria had lead to uraemia, therefore he seemed older than he really was, felt tired, composed less and less and his presence was senile. He felt increased heart symptoms such as dyspnoea, angina pectoris and palpitations. Those symptoms were in progression especially until 2 years before his death. At the end of life he couldn't speak, and he died in the state of semi-consciousness. He died of uraemia at the age of 49 .

\section{Richard Strauss (1864-1944)}

German composer and conductor. During his life he occasionally suffered from more severe diseases, starting from 1891 when he had pneumonia, but he always managed to restore good health. However, he did not take sufficient care for his health during The Second World War, so a lot of difficulties burst out after it, particularly in 1948. He had to treat appendicitis in his 80 's, and then had a complex operation of urinary bladder in Lausanne. After these interventions he recovered very slowly. His general condition worsened in the following years, so he was quite weak when he celebrated his 85th birthday. He had been overtaken with palor, dyspnoea and dizziness, heart problems and had to use oxygen from time to time. As a result of urolithiasis (kidney stones), pyelonephritis, nephrosis and uraemia occurred. He died from the complications of severe urinary system infection and heart failure.

\section{Ferruccio Busoni (1866-1924)}

Italian composer. Due to usage of stimulating chemical drugs, he got chronic inflammation and damage of the cardiac muscle at the end of his life. He died too early at the age of 58. However, the cause of his death was probably a relapse of the kidney infection.

\section{Percy Grainger (1882-1961)}

Australian composer, pianist and musical ethnologist. When he was in his sixties, from 1935 on, he had difficulty urinating, with bladder pains. The tests suggested prostate cancer with pelvic metastases. A suprapubic prostatectomy had been done in Denmark and prostate cancer histological verified. The very painful pelvic metastases were treated with female hormone Stilbestrol and local radiotherapy. Urinary retention was treated with urethral widening procedures. A New York physician, dr. Nygaard, conducted several procedures and at the end, even a bilateral orchidectomy. Severe pains from pathologic fracture in the left hip returned in 1960. Soon Grainger slipped into a coma after a prolonged period of grave psychological disturbances, and died few days later. An autopsy was performed and showed multiple skull bone and meningeal metastases reaching all the way to basal ganglia with brain haemorrhages. The cancer spread throughout maestro's skeletal system, spine, liver and spleen.

\section{Dora Pejačević (1885-1923)}

Croatian composer. At the age of 37 she got post-puerperal fever with uraemia which was the cause of her death 3 weeks later. 
Heitor Villa-Lobos (1887-1959)

The most famous Brazilian composer, conductor, cello player and ethnomusicologist. Eleven years prior to his death, urinary bladder neoplasm, developed from a papilloma, was diagnosed. He had been operated just in time, and thus he had completely recovered and remained professionally active. Two years before his death Villa - Lobos' 70th anniversary was celebrated throughout the world; him still composing vigorously. Nevertheless during his last year his condition became worse due to kidney inflammation and urine stagnation and he died of the uraemia.

\section{Bernard van Dieren (1887-1936)}

English composer and author of DutchFrench-Irish descent. For years he suffered from a chronic inflammation of the bladder causing him a great pain, which he treated with morphine.

\section{Paul Hindemith (1895-1963)}

Well known German neoclassical composer and extremely talented and versatile personality. A violinist, conductor, musical theo- rist, a painter but most of all a born musician blessed with a perfect pitch. In 1924 he married Gertrud Rottenberg, a Jew, which caused him considerable unpleasantness during Nazi regime. Soon after 1933, he was blacklisted by Goebbels. All this made him seek frequent engagements abroad. He built-up the musical life in Turkey and then moved on to Switzerland where he lived till 1940. For reasons of safety he left then for USA where he was active as composer during war years. After the war he lived partly in USA as a professor at Harvard and Yale and in Zurich, and in the later years by the Geneva lake in Switzerland. Short and rather plump, he suffered from cyclothymia and his moods alternated from extreme activity to melancholy and depression. Already in 1959 he suffered a mental breakdown - probably the first signs of progressive arteriosclerosis with high blood pressure. He also suffered from kidney stones and in his later years his creativity visibly deteriorated due to the progressive arteriosclerosis. He suffered several strokes of varying intensity followed by speech impairment, aphasia and pyelonephritis. He spent five weeks in hospital and died rather suddenly. The autopsy revealed the acute pancreatitis as the cause of death.

List of all urological and renal diseases among composers

\begin{tabular}{|c|c|c|c|}
\hline Name & State & $\begin{array}{c}\text { Years of } \\
\text { birth and } \\
\text { death }\end{array}$ & Disease \\
\hline Martin Luther & $\mathrm{DEU}$ & $(1483-1546)$ & kidney stones, collicae, uroliths micturition \\
\hline Giovanni Gabrieli & ITA & $(1533-1612)$ & kidney stones and pyelonephritis \\
\hline Johann Hermann Schein & DEU & $(1596-1630)$ & kidney stones, gout \\
\hline Arcangelo Corelli & ITA & $(1653-1713)$ & intermittent fever - questionable pyelitis \\
\hline Jean Philippe Rameau & FRA & $(1683-1764)$ & questionable febrile pyelonephritis \\
\hline Jean-Jacques Rousseau & FRA & $(1712-1778)$ & dysuria, uraemia \\
\hline Niccolo Jommelli & ITA & $(1714-1774)$ & kidney stones, gout, hypertension \\
\hline Georg Christoph Wagenseil & AUT & $(1715-1777)$ & kidney stones, gout \\
\hline
\end{tabular}




\begin{tabular}{|c|c|c|c|}
\hline Wolfgang Amadeus Mozart & AUT & $(1756-1791)$ & uraemia is not the direct cause of death \\
\hline Niccolo Paganini & ITA & $(1782-1840)$ & gonorrhoea, syphilis, tuberculosis \\
\hline Gioachino Rossini & ITA & $(1792-1868)$ & sever recurrent gonorrhoea \\
\hline Gaetano Donizetti & ITA & $(1797-1848)$ & neurosyphilis with pyelonephritis \\
\hline Vjekoslav Karas & $\mathrm{CRO}$ & $(1821-1858)$ & kidney disorders before suicide \\
\hline Antun Schwarz & $\mathrm{CRO}$ & $(1823-1891)$ & prostate cancer, urinary retention, uraemia \\
\hline Ivan Oertl & CZE & $(1827-1889)$ & oedema of the urinary bladder \\
\hline Modest Petrovich Musorgsky & RUS & $(1839-1881)$ & nephritis, alcoholism, delirium \\
\hline Pyotr-Peter Iyich Tchaikovsky & RUS & $(1840-1893)$ & arsenic poisoning with uraemia, alcoholism \\
\hline Antonin Dvořak & CZE & $(1841-1904)$ & uraemia, stroke \\
\hline Arthur Sullivan & GBR & $(1842-1900)$ & kidney stones, died of a heart attack \\
\hline Ivan Strnad & $\mathrm{CRO}$ & $(1843-1913)$ & prostate hypertrophy \\
\hline Edwars Elgar & GBR & $(1857-1934)$ & genitourinary tract carcinoma \\
\hline Ruggiero Leoncavallo & ITA & $(1858-1919)$ & nephritis, uraemia \\
\hline Isaac Albeniz & ESP & $(1860-1909)$ & nephritis, uraemia \\
\hline Nikola Faller & $\mathrm{CRO}$ & $(1862-1938)$ & uraemia \\
\hline Mijo Majer & $\mathrm{CRO}$ & $(1863-1915)$ & urinary tract inflammation, nephritis, ileus \\
\hline Richard Strauss & DEU & $(1864-1949)$ & pyelonephritis, nephrosis, uraemia \\
\hline Dragutin Farkaš & $\mathrm{CRO}$ & $(1865-1923)$ & uraemia \\
\hline Ferruccio Busoni & ITA & $(1866-1924)$ & died of re-acutization of kidney infection \\
\hline Dragutin Honsa & $\mathrm{CRO}$ & $(1872-1957)$ & uraemia \\
\hline Bogumir Kačerovski & $\mathrm{CZE}$ & $(1872-1945)$ & uraemia, executed \\
\hline Arnold Schönberg & AUT & $(1874-1951)$ & $\begin{array}{l}\text { oedemas and kidney symptoms before } \\
\text { death of heart failure }\end{array}$ \\
\hline Percy Grainger & AUT & $(1882-1961)$ & prostate cancer with multiple metastases \\
\hline Dora Pejačević & $\mathrm{CRO}$ & $(1885-1923)$ & puerperal sepsis, uraemia \\
\hline Roko Šimunaci & $\mathrm{CRO}$ & $(1886-1937)$ & kidney tuberculosis, uraemia \\
\hline Krešimir Benić & $\mathrm{CRO}$ & $(1887-1961)$ & urinary bladder cancer, uraemia \\
\hline Bernard van Dieren & NLD & $(1887-1936)$ & $\begin{array}{l}\text { kidney stones, gallstones, morphine addic- } \\
\text { tion }\end{array}$ \\
\hline Knut Hakanson & SWE & $(1887-1929)$ & renal failure \\
\hline Heitor Villa-Lobos & BRA & $(1887-1959)$ & urinary bladder cancer, uraemia \\
\hline Cole Porter & USA & $(1891-1964)$ & urinary tract infection, kidney stones \\
\hline Vinko Kuničić & $\mathrm{CRO}$ & $(1894-1980)$ & nephropathy, diabetes \\
\hline Ivan Bozzoti & $\mathrm{CRO}$ & $(1895-1935)$ & cystopyelitis \\
\hline Paul Hindemith & $\mathrm{DEU}$ & $(1895-1963)$ & pyelonephritis, pancreatitis \\
\hline Lujza Kozinović & $\mathrm{CRO}$ & $(1897-1975)$ & diabetes, blindness, uraemia, COPD \\
\hline Franjo Šnajder & $\mathrm{CRO}$ & $(1903-1966)$ & prostate cancer \\
\hline Vladimir Berdović & $\mathrm{CRO}$ & $(1906-1980)$ & prostate cancer \\
\hline Ivan Brkanović & $\mathrm{CRO}$ & $(1906-1980)$ & nephrosclerosis, uraemia \\
\hline Hubert Pettan & $\mathrm{CRO}$ & $(1912-1989)$ & urinary tract inflammation \\
\hline Ivo Lhotka Kalinski & $\mathrm{CRO}$ & $(1913-1987)$ & prostate cancer \\
\hline Nico Richter & NLD & $(1915-1945)$ & urinary bladder cancer, uraemia \\
\hline Vladimir Tomerlin & $\mathrm{CRO}$ & $(1920-1979)$ & uraemia \\
\hline
\end{tabular}




\section{Conclusion}

Among the urinary tract diseases, kidney stones, pyelonephritis and uraemia were the most common causes of death. Gout and nephritis have also been mentioned several times as a starting point. There were several neoplastic diseases, especially prostate cancer. Gonorrhoea has been occasionally mentioned (Rossini, Paganini, Rousseau). Mozart probably did not die due to uraemia. All of

\section{References}

1. Sadie S. Grove.: World Encyclopedia of Music. London: Mc Millan; 1980.

2. Lange-Eichbaum W, Kurt W, Ritter W. Genie, Irrsinn und Ruhm. Die Komponisten. Muenchen: Reinhardt; 1986.

3. Kerner D. Krankheiten grosser Musiker, Stuttgart: Schattauer; 1968.

4. Boehme G. Medizinische Portraits beruehmter Komponisten. Sttutgart: Fischer, 1981.

5. Neumayr A. Musik und Medizin, Wien: J \& V.E; 1989.

6. Šostar Z, Vodanović M, Breitenfeld D, Breitenfeld T, Buljan D, Granić R. Composers - substance abusers. Alcoholism 2009;45:127-142.

7. Breitenfeld T. Neurološke i psihijatrijske bolesti skladatelja (magistarski rad). Zagreb: Stomatološki fakultet Sveučilišta u Zagrebu; 2003.

8. O'Shea J. Music and Medicine Medical Profiles of Great Composers, London, Dent\&Sons, 1990.

9. Breitenfeld D, Thaller V, Golik-Gruber V, Breitenfeld T, Bergovec L, Bergovec Ma. Patographies of Famous Musicians - Johann Sebastian Bach, Patography. Alcoholism 1998;34:35-7. the diseases mentioned above had shortened lives of the composers, who lived shoerter than expected and affected their creative work.

\section{Acknowledgements}

None

\section{Conflict of interest}

None to declare

10. Breitenfeld D, Thaller V, Golik-Gruber V, Breitenfeld T, Bergovec L, Šarić V. Patographies of Famous Musicians - Georg Friedrich Händel, Patography. Alcoholism 1996;32/2:163-8.

11. Lewis JW. What Killed the Great and not so Great Composers, Bloomington, Author House, 2010.

12. Breitenfeld D, Breitenfeld T. Bolesti i sudbine poznatih skladatelja, Zagreb, Music Play 2012.

13. Breitenfeld D, Akrap A. Sudbine 111 operetnih skladatelja, Zagreb, Music Play, 2013.

14. Breitenfeld T, Breitenfeld D, Pap M, Katinić K, Kostelić I, Rešetar I. anxiety and Depression Disorders in Composers. Alcohol Psychiatry Res 2015; 51:151-168.

15. Breitenfeld D, Vodanović M, Akrap A, Juran D, Kranjčec D, Vuksanović M. Violent deaths among composers 8accidents, drowning and murders), Alcohol Psychiatry Res 2015;51:49-59.

15. Breitenfeld D, Butković-Soldo S, Raguž H, Kristović D, Zenebe M, Akrap A. Hundred blind and sight impaired composers (nearsightedress excluded unless complicated) with two more extensive patographies (Bach J.S., Handel G.F.), Alcohol Psychiatry Res 2016;52:65-71.

\section{Urološke bolesti 50 kompozitora}

Sažetak - Proučavajući više od tisuću patografija skladatelja pronašli smo pedeset slučajeva uroloških i bubrežnih bolesti među njima. Slučajevi najistaknutijih skladatelja prikazani su u obliku kratkih patografija, dok su ostali navedeni u listi na kraju.

Ključne riječi: urološke, bubrežne, bolesti, kompozitori, glazbenici 
